\title{
16. BIOSTRATIGRAPHY AND PALEOCEANOGRAPHY ACROSS THE EOCENE/OLIGOCENE BOUNDARY AT DEEP SEA DRILLING PROJECT SITE 5491
}

\author{
Scott W. Snyder, Department of Geology, East Carolina University \\ Carla Müller, Geologisch-Paläontologisches Institut der Universität Frankfurt \\ and \\ Kenneth G. Miller, Lamont-Doherty Geological Observatory ${ }^{2}$
}

\begin{abstract}
Drilling at Site 549, located on Goban Spur (Irish continental margin), penetrated an apparently continuous section of upper Eocene/lower Oligocene nannofossil chalks. At $123 \mathrm{~m}$ below seafloor (BSF), a late Eocene planktonic foraminiferal assemblage containing species of Hantkenina and the Globorotalia cerroazulensis group is replaced by a lower diversity, predominantly globigeriniform, early Oligocene assemblage. The base of nannofossil Zone NP21, as determined by the disappearance of Discoaster saipanensis and $D$. barbadiensis, lies at $132 \mathrm{~m}$ BSF. The definition of the Eocene/Oligocene boundary and its recognition using biostratigraphic criteria remain controversial, for many authors (Berggren et al., in press; Hardenbol and Berggren, 1978; Van Couvering et al., 1981) recognize the boundary using the extinctions of planktonic foraminifers (resulting in Zone NP21 straddling the boundary) while others (Martini and Ritzkowski, 1968; Müller, 1979, this volume) correlate the boundary with the base of Zone NP21. Regardless of which boundary criteria are used at Site 549, no dramatic nannofloral or planktonic foraminiferal change occurred at the Eocene/Oligocene boundary. There was a gradual transition from a warm-water to a cool-water assemblage through the late Eocene, with maximal cooling indicated by low-diversity assemblages in lower Oligocene sediments. A bottom-water temperature drop occurred in the late Eocene through early Oligocene as indicated by an ${ }^{18} \mathrm{O}$ enrichment in benthic foraminifers. A major benthic foraminiferal faunal abundance change, from an assemblage dominated by Nuttalides truempyi to one dominated by wide- and long-ranging taxa, occurred in the early late Eocene. No major benthic assemblage changes occurred at the Eocene/Oligocene boundary, although several taxa had first and last appearances in the latest Eocene to earliest Oligocene.
\end{abstract}

\section{INTRODUCTION}

Two holes were cored at Deep Sea Drilling Project (DSDP) Site 549 in the North Atlantic Ocean (latitude $49^{\circ} 05.29^{\prime} \mathrm{N}$, longitude $13^{\circ} 05.89^{\prime} \mathrm{W}$; water depth $2513 \mathrm{~m}$, corrected). Hole 549A (Pleistocene to late Eocene) was hydraulic piston cored; Hole 549 (middle Eocene and older) was rotary drilled.

The composite Eocene/Oligocene sedimentary section within these holes is approximately $278 \mathrm{~m}$ thick. In identifying the Eocene/Oligocene boundary using planktonic foraminifers, there are $206 \mathrm{~m}$ of Eocene and $72 \mathrm{~m}$ of Oligocene sediments. Average sedimentation rates are $20 \mathrm{~m} / \mathrm{m}$.y. for the late Eocene and $13 \mathrm{~m} / \mathrm{m}$.y. for the earliest Oligocene. Lower Eocene sediments are light brown marly chalks; the remainder of the Eocene and the Oligocene sections are bluish-white to light greenishgray nannofossil chalks.

Core recovery averaged $51 \%$ through the upper Eocene and $84 \%$ through the lower Oligocene sedimentary sections. These low recovery rates are somewhat misleading because the length cored by the variable-length hydraulic piston corer (VLHPC) was often only $1 \mathrm{~m}$.

\footnotetext{
${ }^{1}$ Graciansky, P. C. de, Poag, C. W., et al., Init. Repts. DSDP, 80: Washington (U.S. Govt, Printing Office).

2 Addresses: (Snyder) Department of Geology, East Carolina University, Greenville, North Carolina 27834; (Müller) Geologisch-Paläontologisches Institut der Universitā̃, Frankfurt am Main, Germany; (Miller) Lamont-Doherty Geological Observatory, Palisades, New York am Main, 10964 .
}

Also, the poorest recovery was in the lowest part of the upper Eocene section. Core recovery within a $20-\mathrm{m}$ interval on either side of the series boundary (as identified by planktonic foraminifers) averaged $81 \%$. Thus, modest recovery rates still provided the sampling density required for relatively precise stratigraphic interpretations.

There is a disconformity in Hole 549A that spans the early/late Oligocene boundary. It is paleontologically recognizable only by the abbreviated section assignable to nannofossil Zone NP23. A diagonal break in sediments, with fine homogeneous material below and coarser material above, occurs between Sections 5 and 6 of Core 10 (Poag, pers. comm., 1983). This pattern has been observed at other unconformable boundaries in the cores of Leg 80 (Poag et al., this volume). With the exception of this mid-Oligocene disconformity, the Eocene/Oligocene strata at Site 549 appear to represent continuous deposition. If any hiatus occurs in the late Eocene/early Oligocene section, its duration is less than can be resolved by biostratigraphy and isotopic stratigraphy (i.e., less than $0.5 \mathrm{~m}$.y.). This exceptionally thick, largely continuous section provides an opportunity to correlate biostratigraphic and paleoceanographic events associated with the Eocene/Oligocene series boundary.

\section{METHODS}

The stratigraphic distributions of microfossils shown in Figures 1 and 2 are drawn from DSDP Leg 80 contributions by Müller (calcareous nannofossils), Snyder and Waters (planktonic foraminifers), and Miller et al. (benthic foraminifers). A minimum of one sample from 


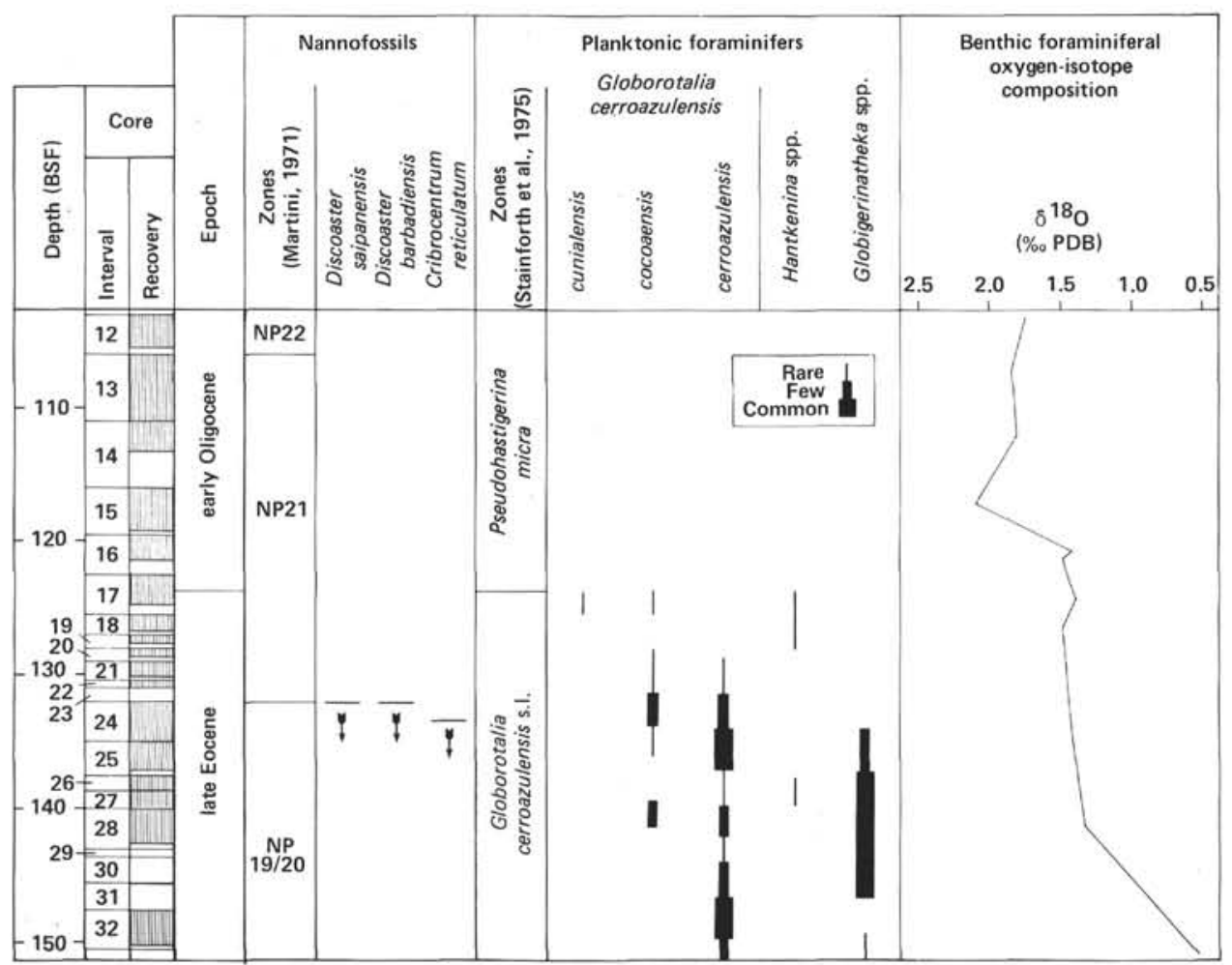

Figure 1. Biostratigraphy and benthic foraminiferal isotopic composition across the Eocene/Oligocene boundary in Hole 549A. (Series boundary plotted according to planktonic foraminiferal evidence. Arrows denote continuation of distributional ranges.)

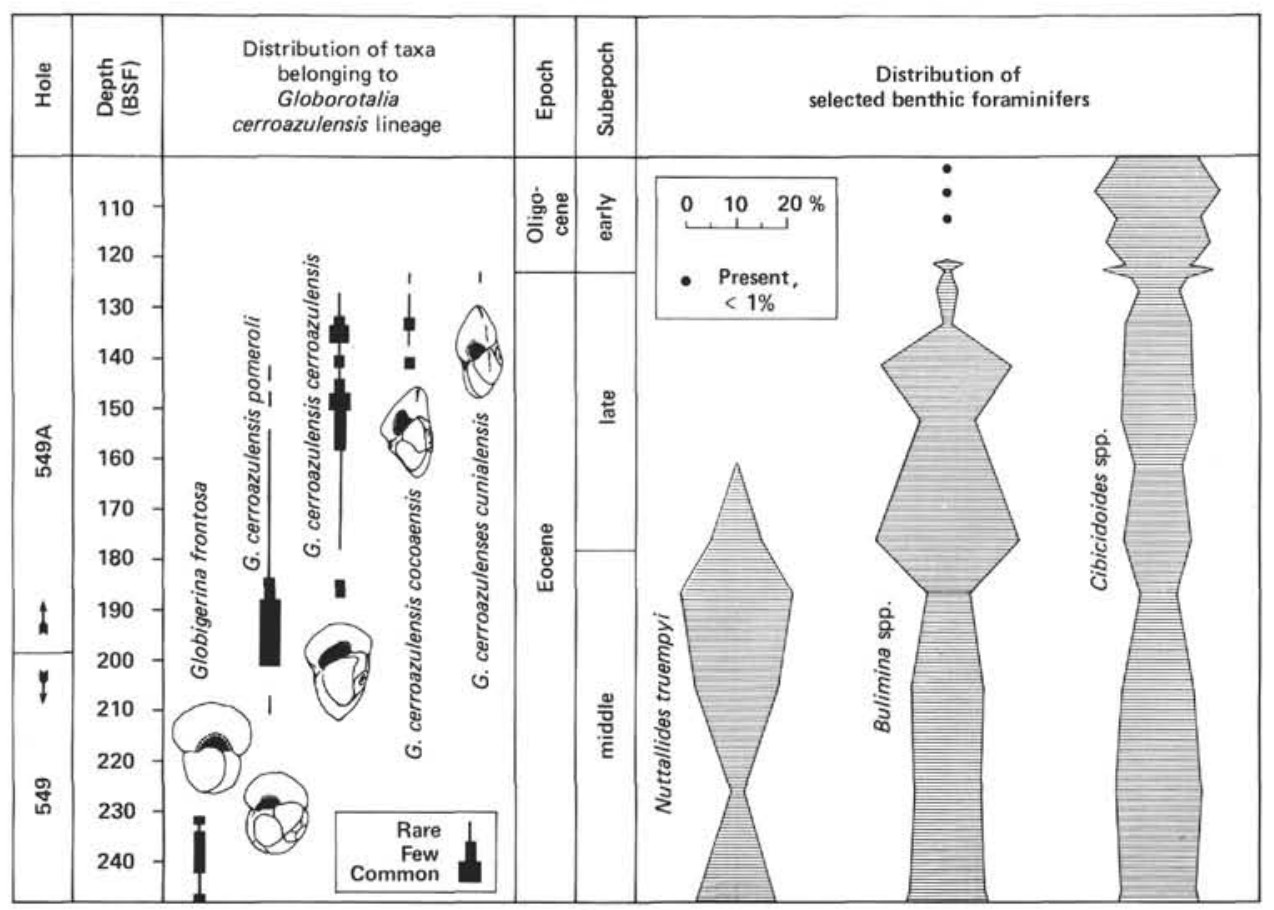

Figure 2. Stratigraphic distribution of selected benthic foraminiferal species compared to the distribution of taxa in the Globorotalia cerroazulensis lineage, Site 549. 
every other section has been examined for planktonic foraminifers. However, many of the shorter VLHPC cores have only one section so the sampling interval is commonly one per section. One and occasionally several samples per section were examined for nannofossils. Benthic foraminiferal and oxygen-isotope analyses are based on 25 samples (Miller et al., this volume), $60 \%$ of which lie in the upper Eocene and lower Oligocene stratigraphic interval.

Recurrent and often extensive downhole contamination was noted in many core-catcher samples, a problem similar to that described by Poore et al. (1982) at South Atlantic DSDP Site 522. Biostratigraphic analyses are, therefore, based largely upon within-core occurrences of taxa. Calcareous nannofossil distributions are expressed in terms of standard NP zones (Martini, 1971). Planktonic foraminiferal distributions are related to the zonal scheme of Stainforth et al. (1975).

The stratigraphic occurrences recorded for selected planktonic foraminiferal taxa represent qualitative abundance estimates based on strewn slides. Nannofossil occurrences are recorded as partial ranges expressed in terms of presence or absence of taxa. Census data for benthic taxa are quantitative counts of aliquots of the $>150 \mu \mathrm{m}$ size fraction and are presented as the percentage of total benthic foraminifers counted. Isotopic analyses were performed on monogeneric samples of the benthic foraminiferal genus Cibicidoides, and results are presented as per mil differences from the PDB standard (Miller et al., this volume).

\section{BIOSTRATIGRAPHY}

The Eocene/Oligocene boundary at Site 549 lies in the lower portion of Hole 549A amid a thick, rather uniform sequence of nannofossil chalks. Upper Eocene through lower Oligocene sediments contain abundant, moderately well preserved nannofossils; well-preserved planktonic foraminifers from this interval show the effects of only minor dissolution and breakage. The Eocene/Oligocene boundary as identified by nannofossils does not coincide with that recognized using planktonic foraminifers, the former lying between Cores 24 and 23 at about $132 \mathrm{~m} \mathrm{BSF}$, and the latter within Core 17 at 123 $m$ BSF. Stratigraphic ranges of taxa used to recognize the boundary are summarized in Figures 1 and 2 .

\section{Foraminifers}

Interpreting middle- to high-latitude biostratigraphy is often difficult because standard planktonic zonations are based on tropical faunas, and the nominate species used to define these zones are frequently absent at higher latitudes. The planktonic foraminifers most useful for recognition of the Eocene/Oligocene boundary at Site 549 are subspecies of Globorotalia cerroazulensis (Cole). Toumarkine and Bolli (1970) described the evolutionary development of this lineage from Globigerina frontosa Subbotina, showing that the stratigraphic ranges of its successive subspecies could be used to subdivide the middle and upper Eocene of higher latitude regions. The stratigraphic occurrences of these subspecies at Site 549 (Fig. 2) correspond closely with the ranges noted by Toumarkine and Bolli. Only one of their subspecies, Globorotalia cerroazulensis possagnoensis, has not been identified at Site 549. The stratigraphic interval where this form might be expected to occur (Hole 549, Cores 4 and 5) is characterized by fairly extensive dissolution and breakage (Snyder and Waters, this volume), and representatives of the $G$. cerroazulensis lineage have not been recovered from it. Miller et al. (this volume) note that this stratigraphic interval is characterized by poorly preserved benthic foraminifers and increased lithification, both suggesting diagenetic alteration.
According to Toumarkine and Bolli (1970), the last appearance datum (LAD) for each of three subspecies (G. cerroazulensis cerroazulensis, $G$. cerroazulensis cocoaensis, and $G$. cerroazulensis cunialensis) marks the Eocene/Oligocene boundary. In Hole 549A G. cerroazulensis cocoaensis and $G$. cerroazulensis cunialensis last appear in Sample 549A-17-2, 30-33 cm, whereas $G$. cerroazulensis cerroazulensis has not been identified above Sample 549A-21-1, 30-33 cm (Fig. 2). The Eocene/Oligocene boundary is placed just above Sample 549A-17-2, 30-33 cm, an interpretation that is supported by the LAD of the genus Hantkenina (also widely used as a marker for this series boundary). Hantkenina alabamensis and $H$. longispina last appear in Samples 549A-17-2, 30-33 cm and 549A-18-1, 30-33 cm, respectively.

Members of the $G$. cerroazulensis lineage are rare and occur somewhat sporadically in samples from the uppermost Eocene. Species of Hantkenina, especially $H$. alabamensis, are rare but consistently present immediately below the boundary recognized by the LAD of subspecies belonging to $G$. cerroazulensis. The susceptibility of all these taxa to dissolution and breakage makes it unlikely that their presence in Cores 18 and 17 is due to reworking. Consequently, their simultaneous disappearance indicates that the Eocene/Oligocene boundary, as identified using the criteria of Toumarkine and Bolli (1970), lies immediately above Sample 549A-17-2, 30$33 \mathrm{~cm}$.

Except for the disappearnace of the $G$. cerroazulensis lineage and species of Hantkenina, there are few changes in planktonic foraminiferal assemblages across the Eocene/Oligocene boundary. Because $G$. cerroazulensis and Hantkenina spp. are rare in upper Eocene sediments, their absence in overlying Oligocene sediments is not a particularly conspicuous faunal change. Lower Oligocen sediments contain slightly lower diversity, predominantly globigeriniform assemblages, but many of these forms are also present in the uppermost Eocene section. The most dramatic and easily recognized faunal abundance change occurs lower within the Globorotalia cerroazulensis (s.1.) Zone (Sample 549A-25-1, 30-33 cm) with the LAD of Globigerinatheka spp. (Fig. 1).

\section{Nannofossils}

The nannofossil-based placement of the Eocene/Oligocene boundary, as interpreted here, coincides with the LAD of certain rosette-shaped discoasters, namely Discoaster saipanensis and $D$. barbadiensis (= base of Zone NP21). Because discoasters are warm-water forms that disappear progressively earlier in higher latitude areas (Van Couvering et al., 1981), their value as biostratigraphic markers at Site 549 might be questioned. However, evidence based on another taxon corroborates the interpretation based on the extinction of $D$. saipanensis and $D$. barbadiensis at Site 549. Müller (1978) noted that Cribrocentrum reticulatum is a useful marker for subdividing Eocene to Oligocene sequences in high latitudes. In fact, where discoasters are absent, she proposed using the LAD of $C$. reticulatum to approximate the position of this series boundary. Its LAD at Site 549 lies in the uppermost Eocene just below the discoaster 
extinction, thus lending credence to identifying the boundary at the latter biostratigraphic event.

The LAD of both $D$. saipanensis and $D$. barbadiensis occurs in Sample 549A-24-1, 10-13 cm. Several specimens of Eocene species, including $D$. saipanensis, are present in Sample 549A-17,CC, but they are considered to be reworked. Thus, the Eocene/Oligocene boundary has been interpreted to lie between Cores 24 and 23, some $9 \mathrm{~m}$ below the foraminifer-based boundary placement.

Neither the nannofossil- nor the foraminifer-based placement of the series boundary is marked by any dramatic change in the nannoflora. The gradual disappearance of warm-water species during middle and late Eocene time, and the occurrence of cold- to temperate-water species (Chiasmolithus oamaruensis, Isomolithus recurvus) in the late Eocene, indicate progressive cooling through this stratigraphic interval. Early Oligocene nannoplankton assemblages exhibit lower diversity, indicating that this was the time of maximum cooling. However, nannofloral evidence suggests a gradual cooling trend rather than any sudden climatic change at or near the boundary.

\section{Foraminifer- versus Nannofossil-Based Boundary Identification}

In some areas, mostly tropical but occasionally at intermediate latitudes, the disappearance of Discoaster saipanensis and $D$. barbadiensis corresponds with that of Hantkenina and the Globorotalia cerroazulensis evolutionary series. Progressive divergence in the timing of these extinction events has been correlated with increasing latitude. At latitudes comparable to Site 549, the discoaster extinction may precede that of Hantkenina and the $G$. cerroazulensis series by as much as a million years (Van Couvering et al., 1981). This conforms roughly to the entire G. cerroazulensis (s.l.) Zone. Resolving the foraminifer- versus nannofossil-based boundary question at Site 549 must involve comparative evaluation of the two interpretations.

The disappearance of $D$. saipanensis and $D$. barbadiensis is used to define the NP20/NP21 zonal boundary, which has traditionally been considered to correspond with the top of the Eocene. This interpretation has recently been disputed. Van Couvering et al. (1981) outlined the conflicting viewpoints as follows: Martini and Ritzkowski (1968) equated the stratotype of the lower Oligocene (Lattorfian) with Zone NP21 and proposed redefining the base of the Oligocene at the base of Zone NP21. However, Cavelier (1979) stated that material from the Lattorfian-type locality lies within Zone NP19/NP20 (late Eocene), a view that agrees with molluscan evidence that also suggests that the base of the Lattorfian is diachronous. Preserving the Lattorfian as a timestratigraphic unit for global reference (1) requires redefinition of its base (impossible since the type locality is not accessible); (2) results in an Oligocene that incorporates an interval normally included in the late Eocene; and (3) creates controversy because it uses a biostratigraphic datum known to be latitudinally time transgressive to define a time-stratigraphic unit. Van Couvering et al. (1981) noted that the Eocene/Oligocene boundary coincides closely with major discontinuities (faunal, floral, physical) in a variety of environments (marine, terrestrial). Basing their interpretation on such criteria, the extinctions of $D$. saipanensis and $D$. barbadiensis, which are still acceptable for defining the NP20/NP21 zonal boundary, occur well below the epoch boundary (i.e., the Eocene/Oligocene boundary lies within Zone NP21). The same boundary-zonal relationship was noted by Hardenbol and Berggren (1978).

Toumarkine and Bolli (1970) suggested that extinction of the G. cerroazulensis lineage marks the Eocene/ Oligocene boundary. The simultaneous disappearance of Hantkenina provides a readily recognizable biostratigraphic event that is present across a broad latitudinal area. Elsewhere, as at Site 549, the extinction of these planktonic foraminifers occurs after that of $D$. saipanensis and $D$. barbadiensis, but prior to the extinction of taxa used to define the top of Zone NP21 (Van Couvering et al., 1981; Poore et al., 1982). A number of workers have correlated this foraminiferal datum with the Eocene/Oligocene boundary (Stainforth et al., 1975; Poore et al., 1982; Snyder and Waters, this volume; Miller et al., this volume). Its dependability is predicated on the assumption that the extinction event is time contemporaneous throughout the world's oceans. The sharp increase $(<0.5 \mathrm{my})$ in $\delta^{18} \mathrm{O}$ in the lowermost Oligocene at Site 549 (Fig. 1; Miller et al., this volume) and at Pacific Sites 277 and 292 (Keigwin, 1980) occurs just above the extinctions of Hantkenina spp. and the $G$. cerroazulensis lineage. Two possibilities therefore exist: (1) the enrichment and the extinctions of planktonic foraminifers are synchronous (a possibility that we favor); or (2) both the enrichment and extinctions are diachronous. Neither has yet been shown to be diachronous, nor does use of these planktonic foraminiferal extinctions present stratigraphic problems such as those associated with placing the boundary at the $D$. saipanensis$D$. barbadiensis extinction. For these reasons, the planktonic foraminifer-based boundary interpretation was used in preparing figures for this chapter. However, it remains to be convincingly demonstrated which, if either, of these identifications of the Eocene/Oligocene boundary is correct (see Conclusions).

\section{PALEOCEANOGRAPHY}

Changes in planktonic foraminiferal and nannofloral assemblages were gradual during late Eocene through early Oligocene time, suggesting that no sudden change in surface waters occurred at the epoch boundary. Characteristics of bottom water during the same interval also changed gradually as indicated by benthic foraminiferal faunal and isotopic composition.

Eocene to early Oligocene benthic foraminiferal assemblage changes are well defined at Site 549 (Miller et al., this volume). At Site 549 ( 2.0-2.5 km paleodepth), the major faunal abundance change was the replacement of a Nuttallides truempyi assemblage just above the middle/late Eocene boundary; this event can be recognized throughout the North Atlantic, South Atlantic, Caribbean, and Gulf of Mexico at this time (Tjalsma 
and Lohmann, 1983; Miller et al., this volume). Other faunal changes at Site 549 included (1) a series of extinctions and local last appearances of taxa in the late Eocene; (2) a series of first appearances (some of which are local) in the late Eocene to earliest Oligocene; and (3) the replacement of a buliminid assemblage just below the Eocene/Oligocene boundary. The record at Site 549 firmly establishes that no major benthic foraminiferal changes (in the $>150 \mu \mathrm{m}$ size fraction) were associated with the Eocene/Oligocene boundary in the North Atlantic. Instead, such changes occurred throughout the late Eocene and earliest Oligocene interval.

In deep abyssal sites ( $>3 \mathrm{~km}$ paleodepth), the benthic faunal change was more dramatic (e.g., Sites 119 and 401 in the Bay of Biscay). Here many abyssal taxa (including Nuttallides truempyi, Clinapertina spp., Abyssamina spp., Aragonia spp., and Alabamina dissonata) became extinct between the middle Eocene and earliest Oligocene (Miller, 1983). Unfortunately, the timing of these extinctions cannot be fully resolved because of a major late Eocene hiatus noted in most deep abyssal locations.

Many of the first and last appearances and the replacement of the buliminid assemblage at Site 549 were probably local phenomena; however, the decreased abundance and the extinctions of Nuttallides truempyi and associated abyssal taxa represent a dramatic benthic foraminiferal change that occurred throughout the Atlantic Ocean (Tjalsma and Lohmann, 1983; Miller, 1983; Miller et al., this volume). During the Cenozoic evolution of deep-sea benthic foraminifers, only the massive extinctions of the latest Paleocene (Schnitker, 1979; Tjalsma and Lohmann, 1983) and assemblage changes of the middle and late Miocene (Douglas and Woodruff, 1982) rival the importance of changes that occurred between the middle Eocene and the early Oligocene.

The benthic foraminiferal isotopic interval reported from the Eocene and Oligocene at Site 549 (Miller et al., this volume) shows that a major enrichment in ${ }^{18} \mathrm{O}$ began in the latest Eocene. This culminated in a rapid ( $<0.5$ m.y.) enrichment just above the Eocene/Oligocene boundary (Fig. 1).

Assuming that the extinctions of planktonic foraminifers used to recognize the Eocene/Oligocene boundary were synchronous, the enrichment correlates with a similar enrichment noted in the Pacific and Southern oceans (e.g., Keigwin, 1980). Although this enrichment may, in part, reflect a seawater compositional change due to ice volume buildup (Matthews and Poore, 1980), it appears to represent a temperature drop of bottom water of at least $2^{\circ} \mathrm{C}$ (Keigwin, 1980; Miller and Curry, 1982; Miller et al., this volume).

\section{CONCLUSIONS}

Biostratigraphic analyses of upper Eocene through lower Oligocene strata at Site 549 have revealed a discrepancy in the timing of certain foraminiferal and nannofossil extinction events generally used to identify the Eocene/Oligocene boundary. Depending upon which fossil group is utilized, the boundary may be placed at 132 $\mathrm{m}$ BSF (extinction of $P$ iscoaster saipanensis and $D$. barbadiensis) or at $123 \mathrm{~m}$ BSF (extinction of the Globoro- talia cerroazulensis lineage and Hantkenina spp.). In preparing this report, the foraminifer-based boundary interpretation has been favored (as evidenced by its use in the figures) for several reasons.

1) The simultaneous extinction of Hantkenina spp. and the G. cerroazulensis lineage is now widely accepted as a biostratigraphic datum that marks the Eocene/Oligocene boundary (e.g., Poore et al., 1982). As Berggren et al. (in press) point out, the scientific validity of an argument is not guaranteed by majority opinion. Nevertheless, the widespread utility of this apparently synchronous datum provides greater consistency than do other paleontological criteria.

2) The boundary identification based on foraminifers agrees well with many correlations between magnetostratigraphic and biostratigraphic scales (e.g., Lowrie and Alvarez, 1981; Berggren et al., in press).

3) The extinction of the G. cerroazulensis lineage appears to be synchronous across broad geographic distances. It occurred within the reverse polarity interval that follows magnetic Anomaly 15 (Lowrie and Alvarez, 1981; Poore et al., 1982). At Site 549 the extinction apparently occurred just at the top of Anomaly 15 (Townsend, this volume), although low magnetic intensities make magnetostratigraphic interpretations tentative. The only other apparent exception to this magnetostratigraphic-biostratigraphic correlation is on the Rio Grande Rise where Pujol (1983) noted the LAD of the G. cerroazulensis lineage at the top of Anomaly 15; this, however, is probably the result of dissolution at Site 516 . The extinction occurred just prior to a sharp $\delta^{18} \mathrm{O}$ increase in the Philippine Sea, Tasman Sea, and Bay of Biscay (Keigwin, 1980; Miller and Curry, 1982; Miller et al., this volume).

4) Identifying the boundary using planktonic foraminifers does not introduce the complex stratigraphic problems associated with use of the discoaster extinction datum (Van Couvering et al., 1981).

However, the Eocene/Oligocene boundary question at Site 549 has not been fully resolved yet. Evidence from Site 549 must be viewed within the context of data from numerous other localities. For example, although the LAD of the Globorotalia cerroazulensis lineage appears to be synchronous, additional documentation is needed. Perhaps the best solution to this problem is the selection of a new, accessible boundary stratotype and the driving of a "golden spike" into this section to mark the boundary. The Jackson/Vicksburg contact in the United States Gulf Coast represents a possible boundary stratotype (see Berggren et al., in press). Of course, before this is done, the location of the spike must be determined-that is, whether to place it in the section at the last appearance of the $G$. cerroazulensis lineage, at the last appearance of the rosette-shaped discoasters, or at yet another faunal or lithic discontinuity. While any current interpretation should be considered provisional, evidence from well-preserved microfossil assemblages of the thick, continuous Eocene/Oligocene section at Site 549 will be pivotal in shaping future interpretations.

Regardless of boundary placement $(123$ or $132 \mathrm{~m}$ BSF), there is no corresponding large-scale change in either the foraminiferal or nannofloral assemblages at 
Site 549. Isotopic evidence indicates a major drop in bottom-water temperature in the earliest Oligocene, but benthic foraminiferal faunas responded gradually to cooling throughout the late Eocene and early Oligocene. Nannofossils and planktonic foraminifers also changed gradually during the late Eocene to cooler water, lower diversity assemblages that are best developed in the early Oligocene. The lack of any dramatic floral or faunal change at the series boundary indicates that there was no traumatic terminal Eocene event at this locality (e.g., Ganapathy, 1982; Alvarez et al., 1982).

\section{ACKNOWLEDGMENTS}

We thank W. A. Berggren and D. V. Kent for their critical review of the manuscript. This is Lamont-Doherty Geological Laboratory contribution number 3591 . Kenneth G. Miller was supported by a Lamont Geological Observatory post-doctoral fellowship.

\section{REFERENCES}

Alvarez, W., Asaro, F., Michel, H. V., and Alvarez, L. W., 1982. Iridium anomaly approximately synchronous with terminal Eocene extinctions. Science, 216:886-888.

Berggren, W. A., Kent, D. V., and Flynn, J. J., in press. Paleogene geochronology and chronostratigraphy. In Snelling, J. J. (Ed.), Geochronology and the Geological Record, Geol. Soc. London, Spec. Paper.

Cavelier, C., 1979. La limite Éocène-Oligocène en Europe occidentale. Sci. Geol., Mem., 54.

Douglas, R. G., and Woodruff, F., 1982. Deep-sea benthic foraminifera. In Emiliani, C. (Ed.), The Ocean Lithosphere, The Sea, Vol. 7: New York (Wiley-Interscience).

Ganapathy, R., 1982. Evidence for a major meteorite impact on the earth 34 million years ago; implication for Eocene extinctions. Science, 216:885-886.

Hardenbol, J., and Berggren, W. A., 1978. A new Paleogene numerical time scale. Am. Assoc. Pet. Geol., Stud. Geol., 6:213-234.

Keigwin, L. D., 1980. Paleoceanographic change in the Pacific at the Eocene-Oligocene boundary. Nature, 287:722-725.

Lowrie, W., and Alvarez, W., 1981. One hundred million years of geomagnetic polarity history. Geology, 9:392-397.

Martini, E., 1971. Standard Tertiary and Quaternary calcareous nannoplankton zonation. In Farinacci, A. (Ed.), Proc. 2nd Ann. Plankt. Conf: Rome (Tecnoscienza), pp. 739-785.
Martini, E., and Ritzkowski, S., 1968. Was ist das "Unter-Oligocän?" Eine analyse der Beyrisch'schen und V. Koenen'schen Fassung der Stufe mit Hilfe des fossilen Nannoplanktons. Akad. Wiss. Göttingen, Nachr., II Math-Phys. K1., 13:231-250.

Matthews, R. K., and Poore, R. Z., 1980. Tertiary $\delta^{18} \mathrm{O}$ record and glacio-eustatic sea-level fluctuations. Geology, 8:501-504.

Miller, K. G., 1983. Eocene-Oligocene paleoceanography of the deep Bay of Biscay: benthic foraminiferal evidence. Mar. Micropaleontol., 7:403-440.

Miller, K. G., and Curry, W. B., 1982. Eocene to Oligocene benthic foraminiferal isotopic record in the Bay of Biscay. Nature, 296: 347-350.

Müller, C., 1978. Remarks on biostratigraphically useful nannofossils in the Paleogene of the northern hemisphere. Strat. Newsl., 7: 45-52.

1979. Calcareous nannofossils from the North Atlantic (Leg 48). In Montadert, L., Roberts, D. G., et al., Init. Repts. DSDP, 48: Washington (U.S. Govt. Printing Office), 589-639.

Poore, R. Z., Tauxe, L., Percival, S. F., Jr., and LaBrecque, J. L., 1982. Late Eocene-Oligocene magnetostratigraphy and biostratigraphy at South Atlantic DSDP Site 522. Geology, 10:508-511.

Pujol, C., 1983. Cenozoic planktonic foraminiferal biostratigraphy of the southwestern Atlantic (Rio Grande Rise): Deep Sea Drilling Project Leg 72. In Barker, P. F., Carlson, R. L., Johnson, D. A., et al., Init. Repts. DSDP, 72: Washington (U.S. Govt. Printing Office), 623-673.

Schnitker, D., 1979. Cenozoic deep water benthic foraminifera, Bay of Biscay. In Montadert, L., Roberts, D. G., et al., Init. Repts. DSDP, 48: Washington (U.S. Govt. Printing Office), 377-413.

Stainforth, R. M., Lamb, J. L., Luterbacher, H., Beard, J. H., and Jeffords, R. M., 1975. Cenozoic planktonic foraminiferal zonation and characteristics of index forms. Univ. Kansas Paleontol. Contrib., 62:1-425.

Tjalsma, R. C., and Lohmann, G. P., 1983. Paleocene-Eocene bathyal and abyssal benthic foraminifera from the Atlantic Ocean. Micropaleontology, Spec. Publ., 4:1-96.

Toumarkine, M., and Bolli, H. M., 1970. Évolution de Globorotalia cerroazulensis (Cole) dans l'Éocène moyen et superieur de Possagno (Italie). Rev. Micropaleontol., 13:131-134.

Van Couvering, J. A., Aubry, M. P., Berggren, W. A., Bujak, J. P., Naeser, C. W., and Wieser, T., 1981. The terminal Eocene event and the Polish connection. Palaeogeogr., Palaeoclimatol., Palaeoecol., 36:321-362.

Date of Initial Receipt: April 11, 1983

Date of Acceptance: July 18, 1983 